\title{
Longitudinal Taphonomic Studies of Mammal Carcasses from the Rio Salado Valley, Mendoza, Argentina
}

\author{
Clara Otaola ${ }^{1^{*}}$ and Alfonsina Tripaldi ${ }^{2}$ \\ ${ }^{1}$ Instituto Multidisciplinario de Historia y Ciencias Humanas (IMHICIHU), Consejo Nacional de Investigaciones Científicas y \\ Técnicas (CONICET), Buenos Aires, Argentina. ${ }^{2}$ Instituto de Geociencias Básicas, Aplicadas y Ambientales (IGEBA), Consejo \\ Nacional de Investigaciones Científicas y Técnicas (CONICET) and Departamento de Ciencias Geológicas, Universidad de \\ Buenos Aires, Buenos Aires, Argentina. \\ *claraotaola@conicet.gov.ar
}

\begin{abstract}
Taphonomic studies aid in understanding the transition of organic matter from living contexts (the biosphere) to geological contexts (the lithosphere), and how agents and processes affect skeletal remains in the archaeological record. Archaeological research in the Atuel River valley, Mendoza, Argentina, has been carried out for several years. However, actualistic approaches to examine local and regional taphonomic processes have only been recently developed in this area. Longitudinal studies of disarticulation and dispersion of bones from carcasses are presented here in order to understand how skeletal materials are naturally added to, subtracted from, and mixed within the archaeological record. In this paper we explore variability in the influence of taphonomic processes in different microhabitats of the valley and how these mechanisms impact the potential of mixing during bone deposition in the archaeological record. There are some qualitative differences between carcasses deposited in different landforms, showing that each place has its own taphonomic history, principally influenced by the geomorphic and ecologic processes that operate in different landforms.
\end{abstract}

Received September 5, 2015

OPEN ひACCESS

Accepted January 11, 2016

DOI 10.14237/ebl.7.1.2016.478

Keywords Taphonomy, Actualistic studies, Mountain environments, Zooarchaeology

Copyright (C) 2016 Otaola and Tripaldi; licensee Society of Ethnobiology. This is an open-access article distributed under the terms of the Creative Commons Attribution-NonCommercial 4.0 International Public License (https://creativecommons.org/licenses/by-nc/4.0), which permits non-commercial use, distribution, and reproduction in any medium, provided the original author and source are credited.

\section{Introduction}

Taphonomy is the study of the processes that have acted on organisms during passage from the biosphere to the lithosphere (Efremov 1940). It was first developed among paleontologists, but since the middle of last century, it has been adopted by archeologists interested in understanding the paleoecological context of hominin evolution and causes of bone modifications (Behrensmeyer and Kidwell 1985; Brain 1967, 1981). Longitudinal studies of carcass disarticulation and bone dispersion contribute to an understanding of how skeletal materials are naturally added to, subtracted from, and mixed within the archaeological record (Borrero 2007; Weigelt 1989). These studies focus on the variability of taphonomic processes within the same taxon in different landscapes (Borrero 2007; Nasti 2000), or on understanding inter-taxonomic differences within the same landscape (Bernáldez Sanchez et al. 2008; Cruz and
Muñoz 2010). Such studies are useful for understanding differences in bone preservation related to variability in skeletal anatomy and differences in environmental setting (see Andrews and Cook 1985; Andrews and Whybrow 2005; Behrensmeyer 1991; Bernáldez Sánchez et al. 2008; Borella and Borrero 2010; Cruz 2007; Cruz and Muñoz 2010; Haynes 1988; Hill 1979). Additionally, these studies are useful for understanding taphonomic interactions within local ecological communities and their material consequences (marks, bone dispersals, etc.) (Behrensmeyer 2007; Blumenschine 1989; Borrero et al. 2005).

This paper summarizes the first results of a longitudinal taphonomic study set up to investigate the histories of four large ungulate carcasses that were deposited in different microhabitats of the Salado River Valley, Mendoza, Argentina (Figure 1). The objective of these longitudinal studies is to explore the 


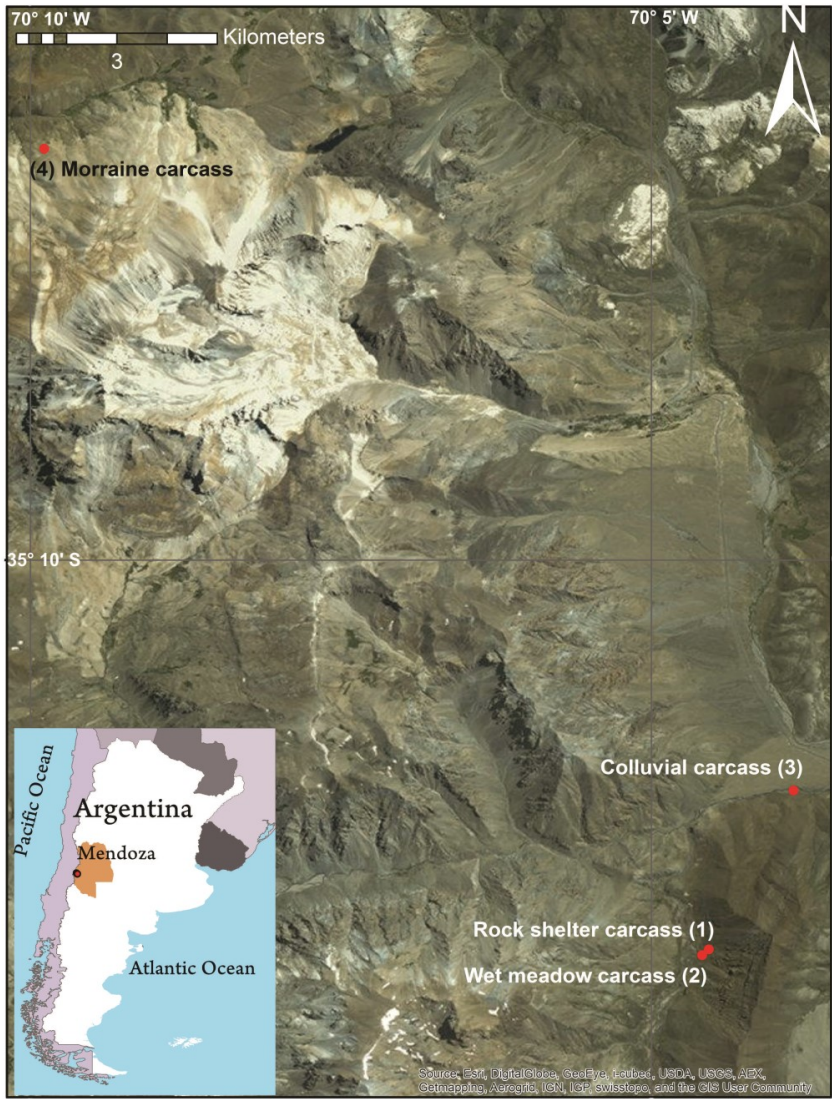

Figure 1 Location of the taphonomic longitudinal study areas in the Rio Salado Valley, Mendoza, Argentina. Satellite image Source Esri, Digital Globe.

variable influence of taphonomic processes in different valley microhabitats and how these mechanisms impact the potential of mixing during bone deposition in the archaeological record. Archaeological research in the Salado River Valley has been carried out for several years (see Lagiglia et al. 1994; Neme 2007); however, this is the first study using actualistic approaches to examine local and regional taphonomic processes. In this paper, one goal was to analyze the influence of post-depositional processes on large mammal carcasses within different geomorphic contexts in a cold high-elevation environment. A second goal was to identify taphonomic variability in order to understand site formation processes through deposition of faunal remains within different landforms on the same river valley.

\section{Methods and Materials}

Carcasses of cattle (Bos taurus) and horses (Equus caballus) with different degrees of skeletonization, disarticulation, and dispersion were selected for this taphonomic study. Carcasses were found in four locations of the Salado River Valley (Andes Cordillera of Mendoza, Figure 1; Table 1), within the Patagonia phytogeographic region (Cabrera 1971). The Patagonian semidesert and steppe average $200 \mathrm{~mm}$ in annual precipitation, with a range of 120-600 $\mathrm{mm}$ (Paruelo et al. 1998). Most rainfall occurs during the winter. This desert is characterized by a xeric bushy steppe of Mulinum spp., Chuquiraga spp., and Festuca spp., among others (Cabrera 1971; Roig et al. 2000). The study area is characterized by low shrub vegetation, mixed with grasses and occasional herbaceous steppe (Capitanelli 2005). The general weather conditions in this area are defined as the desertic arid mountain climatic zone (Abraham and Rodriguez Marínez 2000; Capitanelli 2005).

The locations of the carcasses present different sedimentological and geomorphological characteristics (Figure 2A). The carcass observations were carried out in an area seasonally used by "puesteros," traditional ranchers who live in the Andes and nearby piedmont, and who practice seasonal transhumance (Otaola et al. 2015). This means that the carcasses are deposited in an active herding area and that they might be affected by herding activities. The herded animals are usually goats, but cows and horses also are fed there. Other domestic animals that live among them are dogs. Regarding the native fauna, guanacos (Lama guanicoe), pumas (Felis concolor), and red fox (Pseudalopex culpaeus) are the largest mammals present in the area.

Carcass 1 (C1; rock shelter carcass) was located about $55 \mathrm{~m}$ above the margin of Arroyo Colorado Creek, 35 13 ' 07' south latitude and 70 04' 32.6" west longitude, at $2268 \mathrm{~m}$ asl (Figure 1), under a rock shelter formed by Mesozoic sedimentary rocks outcropping in a colluvial slope (hillslope gradient of 64-67\%). According to information given by the local rancher Mr. Julio Corales, this animal met its death due to starvation two years before our first observation.

Evidence of a recent campfire was found during one of the site visits indicating that the shelter is used by contemporary herders. C1 is located in a dynamic erosional and depositional setting, and some vegetation in the form of bushes grows nearby. The location is characterized by sediments of variable particle size (silt to pebble) from high-energy water currents around debris cones, in addition to rock fall and sedimentation from hillslope creep (Figure 2B). Some bones were partly buried, and in order to check if 

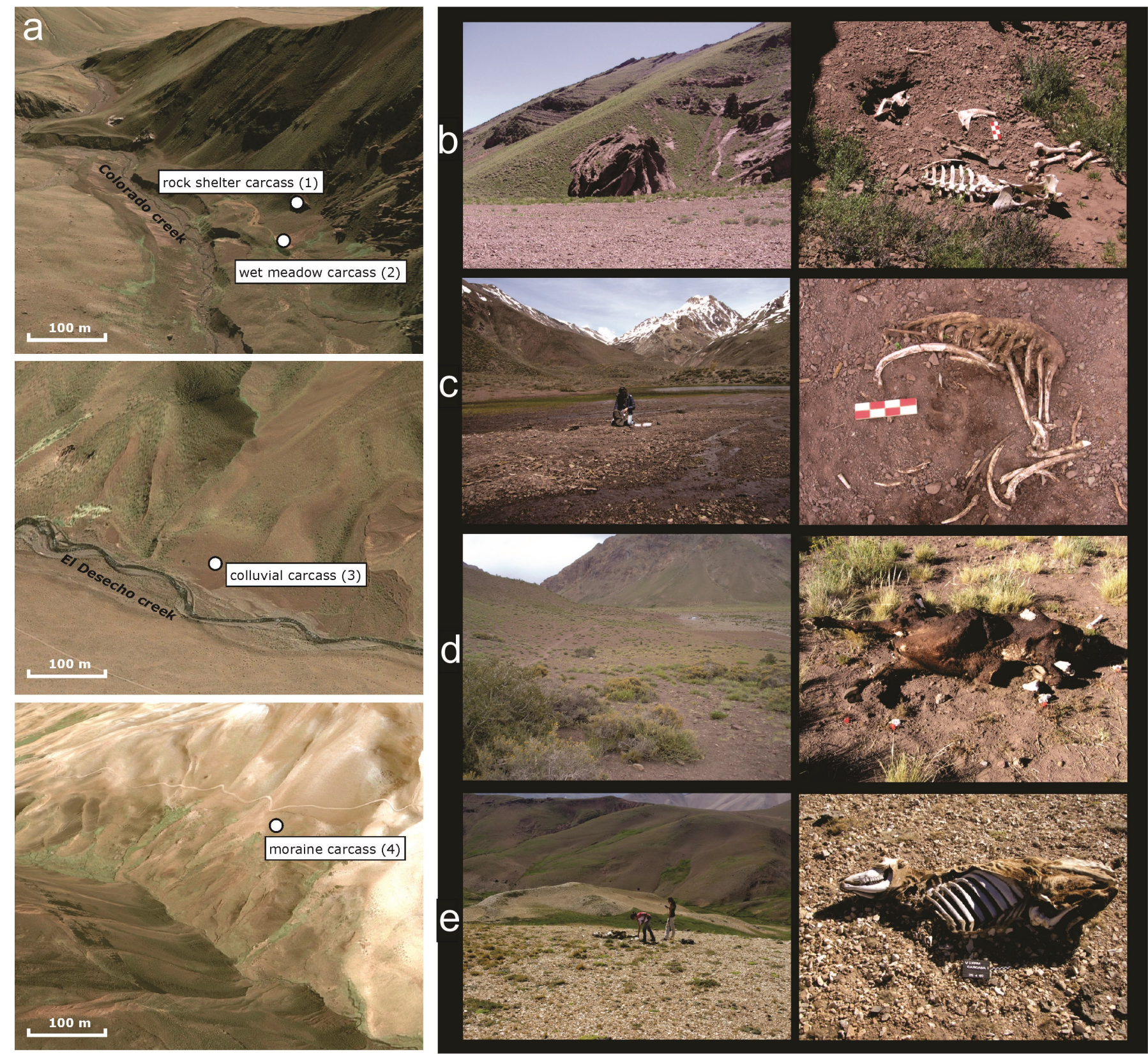

Figure 2 A Satellite view of the landscapes associated with the four carcasses analyzed in this study, B Rock shelter carcass (C1), C Wet meadow carcass (C2), D Colluvial slope carcass (C3), E Glacial moraine carcass (C4). The photos in the right column show the condition of the carcasses during the first stage of observations. Satellite image courtesy of Google Earth.

those bones were part of the skeleton of this carcass, a test pit was excavated in the shelter, the results of which are described below.

Carcass 2 (C2; wet meadow carcass) was located at $35^{\circ} 13^{\prime} 8.02^{\prime \prime}$ south latitude and $70^{\circ} 4^{\prime} 31.04^{\prime \prime}$ west longitude, $2045 \mathrm{~m}$ asl (Figure 1). This carcass was found $\sim 150 \mathrm{~m}$ from carcass $\mathrm{C} 1$, in a wet meadow developed at the apron of a steep colluvial slope (hillslope gradient of 64-67\%) and approximately 25 $\mathrm{m}$ above Colorado Creek, a braided stream incising into glaciofluvial deposits; the nearby vegetation consists of grasses. The wet meadow receives water from a spring and forms a small pond that varies in size due to seasonal rainfall. The totally skeletonized carcass was deposited in silty sediments with $\sim 40 \%$ angular pebbles, accompanied by abundant vegetation 
Table 1 General information on the areas where the carcasses were deposited.

\begin{tabular}{lllll}
\hline Carcass \# & Taxon & Landform & Slope & Date \& Cause of Death \\
\hline C1 & Bos taurus & Rock shelter & $64-67 \%$ & 2007 , starvation \\
C2 & Equus caballus & Wet meadow & $64-67 \%$ & 2008 , starvation \\
C3 & Bos taurus & Colluvial slope & $28-35 \%$ & 2008 , no data \\
C4 & Bos taurus & Glacial moraine & $28-38 \%$ & No date, no data \\
\hline
\end{tabular}

due to the humidity of the meadow (Figure 2C). This animal met its death twelve months before our observations, according to the details given by the same local rancher.

Carcass 3 (C3; colluvial carcass) was deposited $\sim 80 \mathrm{~m}$ above the braided plain of El Desecho Creek, at $35^{\circ} 11^{\prime}$ 54" south latitude and $70^{\circ} 03^{\prime} 48^{\prime \prime}$ west longitude, $2065 \mathrm{~m}$ asl (Figure 1) on poorly sorted colluvium (silt-sand to angular pebbles) related to debris cones with a $28-35 \%$ hillslope gradient. According to local ranchers, this carcass was deposited twelve months before our first observation in 2008. Vegetation near C3 is sparse, but present in the form of bushes and grasses. This carcass was less skeletonized than $\mathrm{C} 1, \mathrm{C} 2$, and $\mathrm{C} 4$, and most of the elements were articulated. Archaeological materials were found in the surrounding area (Figure 2D).

Carcass 4 (C4; moraine carcass) was deposited at $35^{\circ} 06^{\prime} 25.9^{\prime \prime}$ south latitude and $70^{\circ} 08^{\prime} 48.4^{\prime \prime}$ west longitude, $2815 \mathrm{~m}$ asl (Figure 1) at mid-slope of a high gradient hillslope (28-38\%), $130 \mathrm{~m}$ above the valley floor of a creek that drains to the west. C4 was deposited in a partially eroded glacial moraine composed of angular pebbles to fine boulders. The vegetation is sparse, with only some grasses from the Patagonian steppe (Figure 2E).

Study observations were planned in two stages. The first stage lasted one year and consisted of regular visits every three months at the midpoint of each season. In the second stage, observations were made once per year, during the summer. In this paper we present data from observations made during three summers, starting from the first observation (summer of 2009) in order to make comparisons at one-year intervals.

All carcasses were in different stages of skeletonization, disarticulation, and dispersion at the start of the longitudinal observations (see Figure 2, right column); however, our observations are useful for making comparisons about the speed at which many taphonomic variables affect skeletal remains in different microhabitats of this mountain landscape.
The variables studied here include disarticulation, dispersion, weathering, burial (measured by the partly buried elements), post-depositional damage made by animals, and extent of fragmentation. In each area, carcass and bone dispersion were mapped. Then, each of the skeletonized elements was tallied and analyzed following the same methodology we used for analyzing zooarchaeological specimens from archaeological sites in the region (Otaola 2013).

Disarticulation was measured by tallying the Minimum Number of Elements (MNE) observed, and dispersion by measuring the extent of bone distribution. Stages of disarticulation are described following Cruz and Muñoz (2010), and stages of dispersion follow Hill (1979). Burial process was evaluated by considering those bones that were partially buried (Borrero et al. 1993) and bone weathering was estimated considering Behrensmeyer's (1978) scale. This measurement helps to describe the level of bone destruction since death and is related to the local conditions of temperature, humidity, and soil chemistry. The weathering scale proposed by Behrensmeyer is a tool used to describe, in an ordinal scale, the level of destruction of the assemblages. The scale has six stages, ranging between 0 to 5 , with bones in stage 0 characterized as bones with no signs of cracking, which still have grease and skin, and ligaments may cover part or all of the bone's surface. On the other extreme of the scale, stage 5 describes bones almost destroyed, which are easily broken by moving (Behrensmayer 1978:151).

Table 2 MNE of the four carcasses tallied in each observation.

\begin{tabular}{llll}
\hline & \multicolumn{3}{c}{ MNE } \\
\cline { 2 - 4 } Carcass \# & $\mathbf{2 0 0 9}$ & $\mathbf{2 0 1 0}$ & $\mathbf{2 0 1 1}$ \\
\hline C1 & 29 & 35 & 31 \\
C2 & 49 & 3 & 11 \\
C3 & 13 & 50 & 52 \\
C4 & 13 & 9 & 13 \\
\hline
\end{tabular}



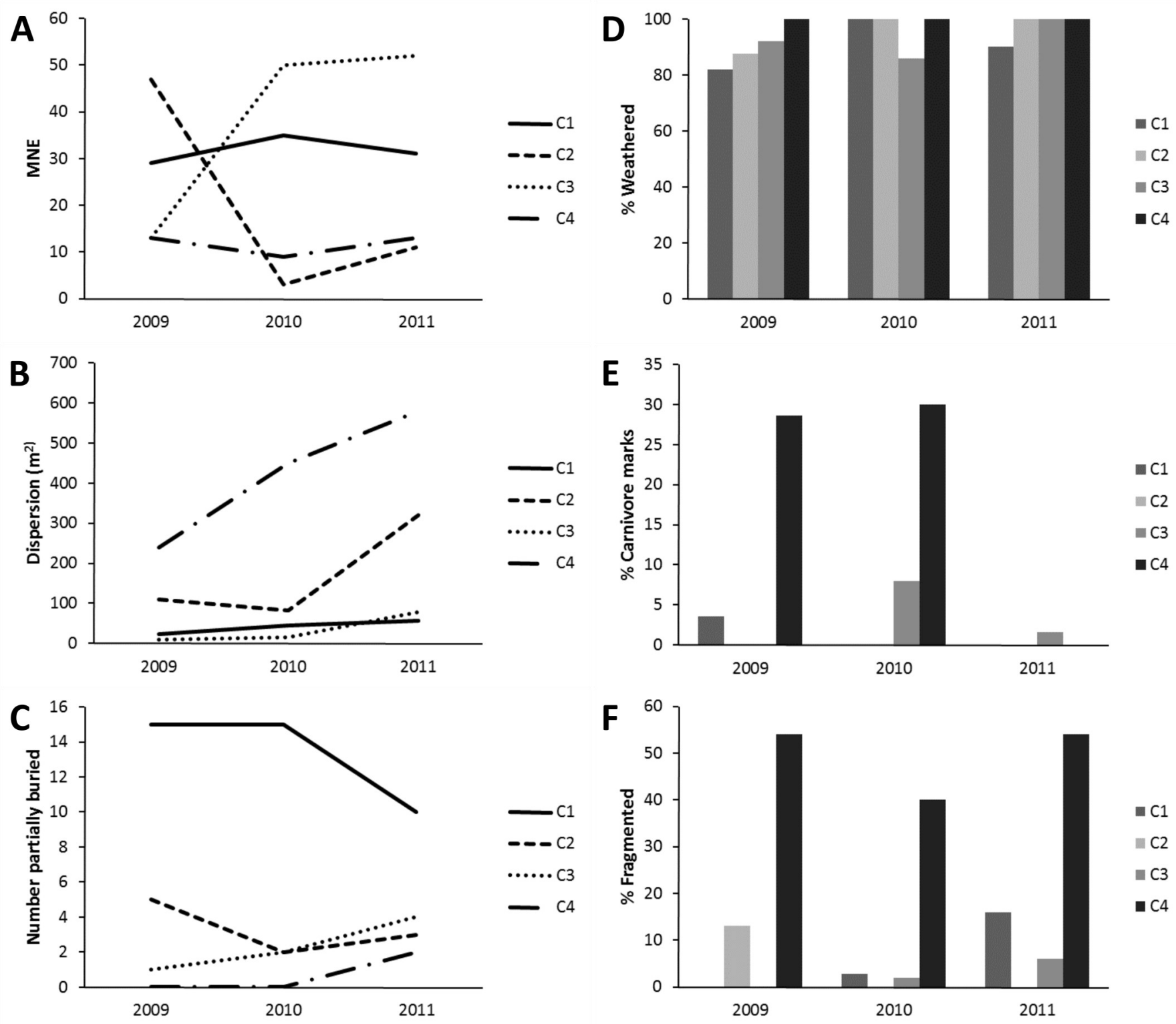

Figure 3 Modification of the carcasses across time. A MNE, B bone dispersal, C number of bones partially buried, D percentage of bones with weathering present, $\mathbf{E}$ percentage of bones with carnivore marks present, $\mathbf{F}$ percentage of fragmented bone.

Animal activities were evaluated through the examination of bone surface modifications, such as gnaw marks or trampling fractures, following criteria proposed by Lyman (1994). These variables were then analyzed in terms of change over time within sites and spatial variability between carcasses.

\section{Results}

\section{Bone element frequencies}

Skeletal part frequencies at the beginning of the observations vary according to the original level of observed carcass skeletonization. Rock shelter and wet meadow carcasses were the most skeletonized at the beginning of these studies and colluvial slope and moraine carcasses had more soft tissue surrounding bones (Table 2; Figure 3). The rate of carcass disarticulation varies by site. Rock shelter (C1) and moraine (C4) carcasses maintained a consistent MNE over the three years of observations. In contrast, there was a decrease in MNE from the wet meadow carcass (C2) 
Table 3 Dispersal of the carcasses measured in meters squared in each observation.

\begin{tabular}{llll}
\hline & \multicolumn{3}{c}{ Dispersal $\left(\mathbf{m}^{2}\right)$} \\
\cline { 2 - 4 } Carcass \# & $\mathbf{2 0 0 9}$ & $\mathbf{2 0 1 0}$ & $\mathbf{2 0 1 1}$ \\
\hline C1 & 24 & 45 & 56 \\
C2 & 110 & 82 & 320 \\
C3 & 9 & 16 & 78 \\
C4 & 240 & 450 & 580 \\
\hline
\end{tabular}

over time, indicating that this microenvironment is highly dynamic. At initial observation, the colluvial slope carcass (C3) was in early stages of disarticulation; as a result, MNE increased over time as more elements became skeletonized (Figure 3A).

Dispersion

Once the elements became disarticulated from the carcass, the process of dispersion and/or burial began. This process is conditioned by the energy of depositional processes (mainly related to slope gradient), the kind of sediments, and animal activities that disperse skeletal elements in each area. In our observations, wet meadow (C2) and moraine carcasses (C4) had higher dispersion rates than those located in the rock shelter (C1) and colluvial slope (C3) areas. This difference is likely related to carcass location, as C4 lies at the mid-slope of a steep hillside and C2 on a wet meadow, a microenvironment with a high sedimentation rate due to frequent flooding. Moreover, the wetland (C2) is a water source that attracts many animals, which contribute to the disarticulation of carcasses and the dispersion of bones. In addition, the drainage of the wet meadow likely contributed to the erosion and transport of bones. The rock shelter carcass (C1) is protected by the wall of the shelter, and the colluvial slope carcass (C3) was less disarticulated at the beginning of the observations because it was not fully skeletonized (Table 3; Figure 3B).

Bone modification

Bone damage is an important consideration for evaluating the potential loss of identifiability of faunal specimens. Weathering, fragmentation, and carnivore damage are considered here. It is important to mention that snow covers all the carcasses during winter, and that $\mathrm{C} 1$ was covered by snow until springtime, as the shadow of the rock shelter prevents snow from melting quickly. At the beginning of the study each carcass had at least $80 \%$ of skeletonized elements weathered (Table 4). Lower stages were present in the first observations, and all stages in the last (Figure 4). It is expected that weathering increases with time, and this was observed in C2 and C3. However, some differences were observed between carcasses. The carcass located in the rock shelter (C1) showed an increase in the number of bones weathered in the second observation, with all the elements weathered, but in the fifth observation there were some unweathered bones due to the re-exposure of previously buried specimens (Figure 3D; Figure 4).

Animal agents affecting carcasses produced carnivore (Figure 5) and trampling marks on bone surfaces. In another taphonomic study carried out in this area, it was observed that carnivores are one of the main agents affecting animal bones in open-air sites (Otaola 2014). The rock shelter carcass (C1) has only a few bones with evidence of carnivore gnawing, and the wet meadow carcass (C2) did not show any evidence of this kind of damage. The carcass located in the colluvial slope (C3) did not exhibit carnivore activity in the first observation, however, this changed in the second observation, when we observed the appearance of gnawing on some bones. The moraine carcass (C4) exhibited the most evidence of this kind of damage in the first two observations, but in the last one, there were no bones with gnaw marks (Figure 3E; Table 4), which suggests that they were carried away or completely destroyed.

Bones were not highly fragmented in most of the carcasses. C4 (moraine) produced the highest frequency of fragmented bones in all the observations. In the rock shelter carcass (C1), one of the bones was fractured in the second observation and only five elements were fractured by the end of this study. The

Table 4 Bone modifications of the four carcasses analyzed in this study over three observation periods.

\begin{tabular}{|c|c|c|c|c|c|c|c|c|c|c|c|c|c|c|c|c|c|c|}
\hline \multirow[b]{2}{*}{ Carcass \# } & \multicolumn{6}{|c|}{ Weathering } & \multicolumn{6}{|c|}{ Fragmentation } & \multicolumn{6}{|c|}{ Carnivore marks } \\
\hline & & $1^{\text {st }}$ & & $2^{\text {nd }}$ & & $3^{\text {rd }}$ & & $1^{\text {st }}$ & & $2^{\text {nd }}$ & & $3^{\text {rd }}$ & & $1^{\text {st }}$ & & $2^{\text {nd }}$ & & $3^{\text {rd }}$ \\
\hline $\mathrm{C} 1$ & 23 & $79 \%$ & 35 & $100 \%$ & 27 & $100 \%$ & 0 & $0 \%$ & 1 & $3 \%$ & 5 & $16 \%$ & 1 & $4 \%$ & 0 & $0 \%$ & 0 & $0 \%$ \\
\hline $\mathrm{C} 2$ & 25 & $88 \%$ & 3 & $100 \%$ & 10 & $91 \%$ & 6 & $13 \%$ & 0 & $0 \%$ & 0 & $0 \%$ & 0 & $0 \%$ & 0 & $0 \%$ & 0 & $0 \%$ \\
\hline C3 & 12 & $92 \%$ & 45 & $90 \%$ & 48 & $92 \%$ & 0 & $0 \%$ & 2 & $4 \%$ & 3 & $6 \%$ & 0 & $0 \%$ & 2 & $4 \%$ & 2 & $3 \%$ \\
\hline $\mathrm{C} 4$ & 13 & $100 \%$ & 9 & $100 \%$ & 13 & $100 \%$ & 7 & $54 \%$ & 4 & $40 \%$ & 7 & $64 \%$ & 4 & $28 \%$ & 3 & $30 \%$ & 0 & $0 \%$ \\
\hline
\end{tabular}



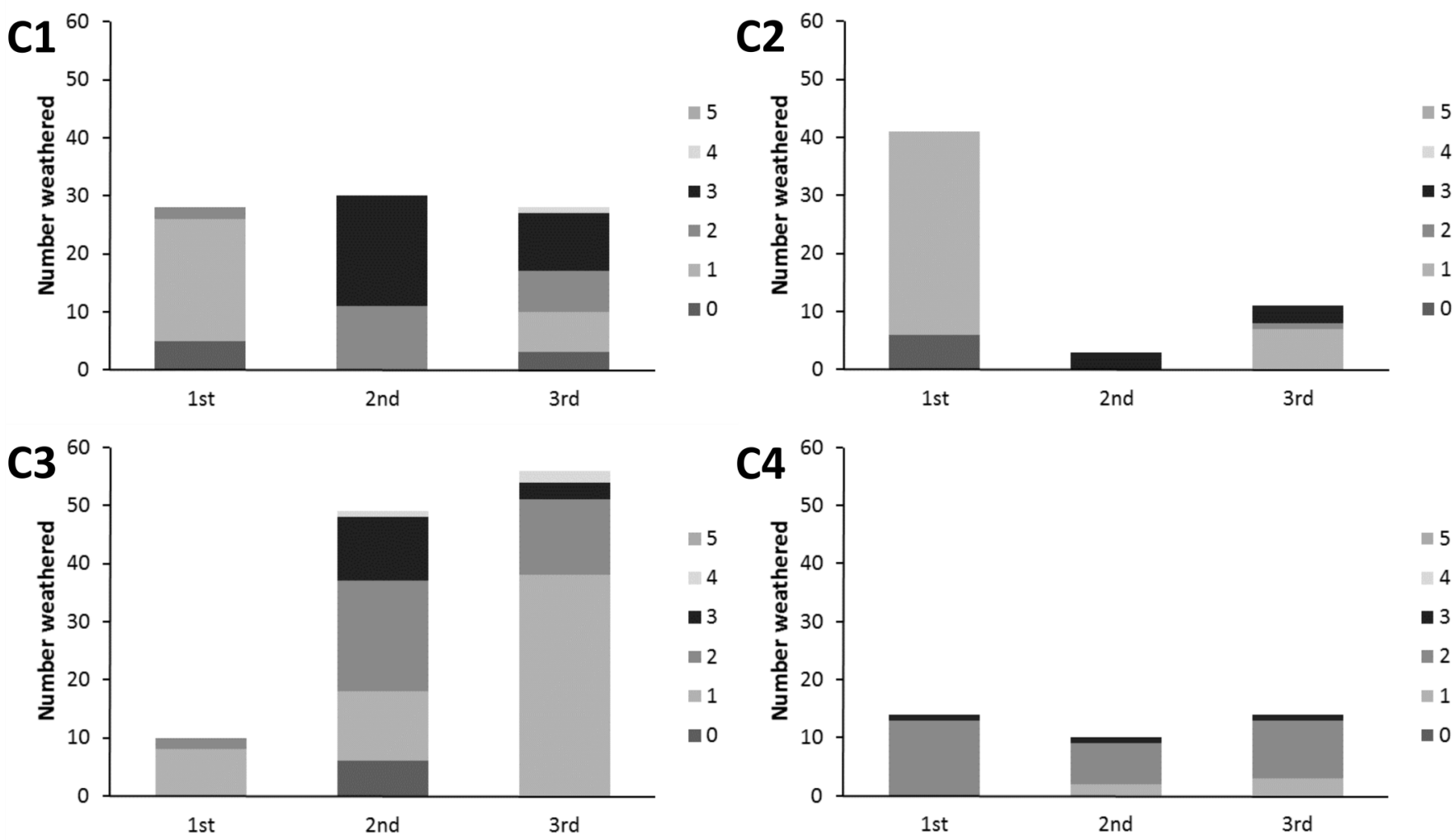

Figure 4 Weathering observed in each carcass, considering the weathering stage (0-5; sensu Behrensemeyer 1978) of each bone. C1 Rock shelter carcass, C2 Wet meadow carcass, C3 Colluvial slope carcass, and C4 Glacial moraine carcass. Each bar represents the number of bones weathered in the different weathering stage tallied in each observation (one-year interval).

fractured bones included ribs with mechanical fractures, possibly caused by domestic animal trampling. In the wet meadow carcass (C2), intensive fragmentation was not observed, since the only fractured bones were registered in the first observation and no other fragmented bone was detected in the following examinations. Finally, the colluvial slope carcass (C3) showed only two or three fractured bones in the second and third observations, respectively, which may have been caused by trampling by other domesticate ungulates (horses and cows) in the area (Figure 3F).

\section{Burial}

Regarding the burial of skeletal elements in these different landforms, variability is also related to the geomorphic and sedimentary context of each carcass (Table 5). In the rock shelter (C1), the amount of partially buried bones diminished over time. This area receives coarse-grained sediments that buried bones quickly and, at the same time, some of them were reexposed by animal bioturbation (Figure 6). For the wet meadow carcass (C2), the number of specimens visible at the surface varied according to the seasonal variation of water level in the meadow. Here, the accumulation of sediments caused rapid burial of most parts of the carcass. A similar burial pattern was observed at Bahia San Pablo, Tierra del Fuego with comparable waterlogged contexts in which elements were buried before becoming weathered (Borrero 2007). Carcass C3, located on a colluvial slope, exhibited a small amount of bone burial, which increased over time. Finally, in the moraine context (C4), only two second phalanges appeared partially buried, and were recorded during the final observation (Figure 3C).

\section{Excavations near Carcass 1}

During the first observation of Carcass 1, a long bone was emerging from the subsurface (Figure 7A). A 1 $\mathrm{m}^{2}$ test pit was excavated in order to examine the depth of bone deposition. Excavation followed artificial levels of $10 \mathrm{~cm}$ each. A total of four levels were excavated. In level one, two bone specimens 


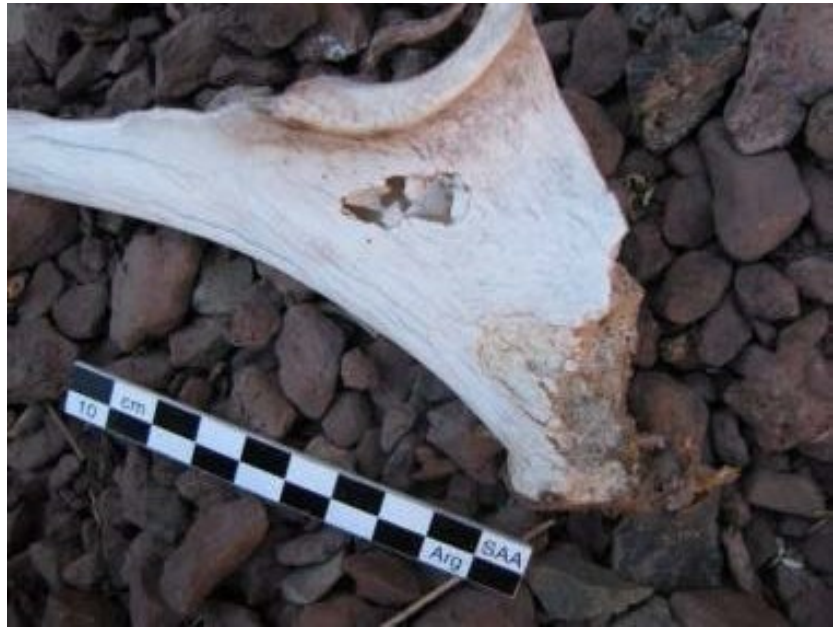

Figure $\mathbf{5}$ The carnivore damage present in Carcass 1.

were found: a rib and an unidentifiable bone, the first one was in stage 3 of weathering (sensu Behrensmeyer 1978) and the other bone at stage 1. In the following level, six Bos taurus bones were found and identified as being specimens from carcass 1 (Figure $7 \mathrm{~B}$ and $\mathrm{C}$ ). The recovered elements in this level were a radius, metapodial, first and second phalanges, two tarsals, all of the same laterality and complete, without biotic modifications and unweathered, except for the distal portion of the radius which was the bone that was emerging from the surface. The deepest bone of the carcass was deposited $38 \mathrm{~cm}$ from surface, which shows that, at least, in that part of the shelter, $38 \mathrm{~cm}$ of sediments were deposited in two years, suggesting a high sedimentation rate. In level three, we found a peach pit, a carbon fragment, and a medium sized mammal rib. In the last level (level four), no other

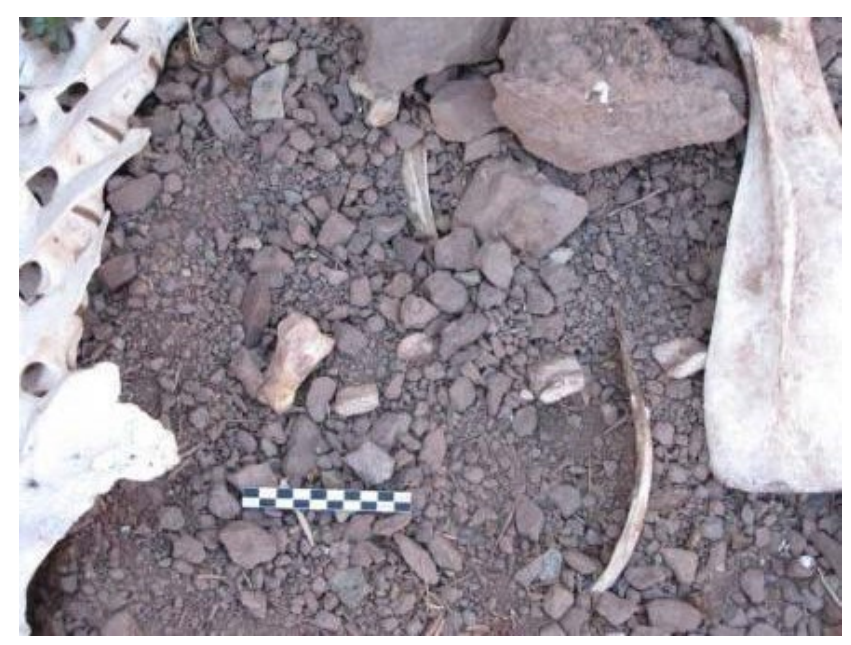

Figure 6 Partly buried elements at Carcass 1 location.
Table 5 Partly buried bones observed in each carcass during three years of observations.

\begin{tabular}{lllllll}
\hline & \multicolumn{5}{c}{ Partially buried } \\
\cline { 2 - 7 } Carcass \# & \multicolumn{2}{c}{$\mathbf{2 0 0 9}$} & \multicolumn{2}{c}{$\mathbf{2 0 1 0}$} & \multicolumn{2}{c}{$\mathbf{2 0 1 1}$} \\
\hline C1 & 15 & $51 \%$ & 15 & $42 \%$ & 10 & $31 \%$ \\
C2 & 5 & $10 \%$ & 2 & $66 \%$ & 3 & $27 \%$ \\
C3 & 1 & $8 \%$ & 2 & $4 \%$ & 4 & $7 \%$ \\
C4 & 0 & $0 \%$ & 0 & $0 \%$ & 2 & $15 \%$ \\
\hline
\end{tabular}

materials were found, so we decided to stop the excavation there.

\section{Discussion}

The archaeological record displays an average of taphonomic conditions in which human, other biotic, and abiotic processes influence faunal remains (Wolverton et al. 2014). Some attributes of noncultural assemblages are virtually indistinguishable from attributes that archaeologists have believed to be created by human behavior alone, and others are now identifiable as non-cultural traits thanks to an extensive list of actualistic taphonomic studies carried out in the last decades.

Even though the present study has a lack of control of some variables, something which is expected from actualistic naturalistic studies (sensu Marean 1995), it gives some clues that could help zooarchaeologists to build taphonomic models of the factors that could affect faunal record in rock shelters, wet meadows, colluvial slopes, and moraine settings. Qualitative differences between carcasses deposited in the analyzed landforms are summarized in Table 6.

The context with the highest sedimentary depositional rate was the wet meadow (C2), followed by the rock shelter (C1), and finally the colluvial slope setting (C3) and the glacial moraine (C4), which have the highest slope gradient and are associated with carving and gullying. Regarding taphonomic processes associated with vertical migration and burial, the wet meadow (C2) and the rock shelter (C1) are the most dynamic settings. In the rock shelter the potential mixing of archaeological materials with contemporary materials is high, as demonstrated by rapid burial of some elements but not others, even though horizontal movement of bones is limited by the shelter wall. Vertical migration is more likely to occur due to sedimentary contributions from the colluvial slope and from faunal and human activities. The latter could be inferred by the presence of hearth ashes and gnaw

Otaola and Tripaldi. 2016. Ethnobiology Letters 7(1):1-13. 
Table 6 Qualitative variation of postdepositional processes measured in this study.

\begin{tabular}{lllll}
\hline & \multicolumn{4}{c}{ Carcass \# } \\
\cline { 2 - 5 } Variable & Rock shelter & Wet meadow & C3 & Colluvial slope \\
\hline Landform & Bos taurus & Equus caballus & Bos taurus & Glacial moraine \\
Taxon & High & High & Low & Null \\
Depositional rate & Moderate & High & High & Low \\
Weathering & High & Moderate & High \\
Horizontal Dispersion & Low & High & Low & Null \\
Vertical Migration & Moderate & & &
\end{tabular}

marks on bones. In the wet meadow, vertical migration and horizontal movement were high, which indicates that mixing of archaeological deposits would be likely. However, because materials are buried somewhat rapidly, faunal preservation could be enhanced. As we mentioned above, in the moraine and colluvial contexts vertical migration is low. In these two sites, horizontal dispersion seems to be more problematic than vertical movement of carcasses and bones.

The level of fragmentation and carnivore damage is not high for any of the carcasses. As shown in Table 4, fragmentation was observed in a few elements of each carcass, and carnivore damage was

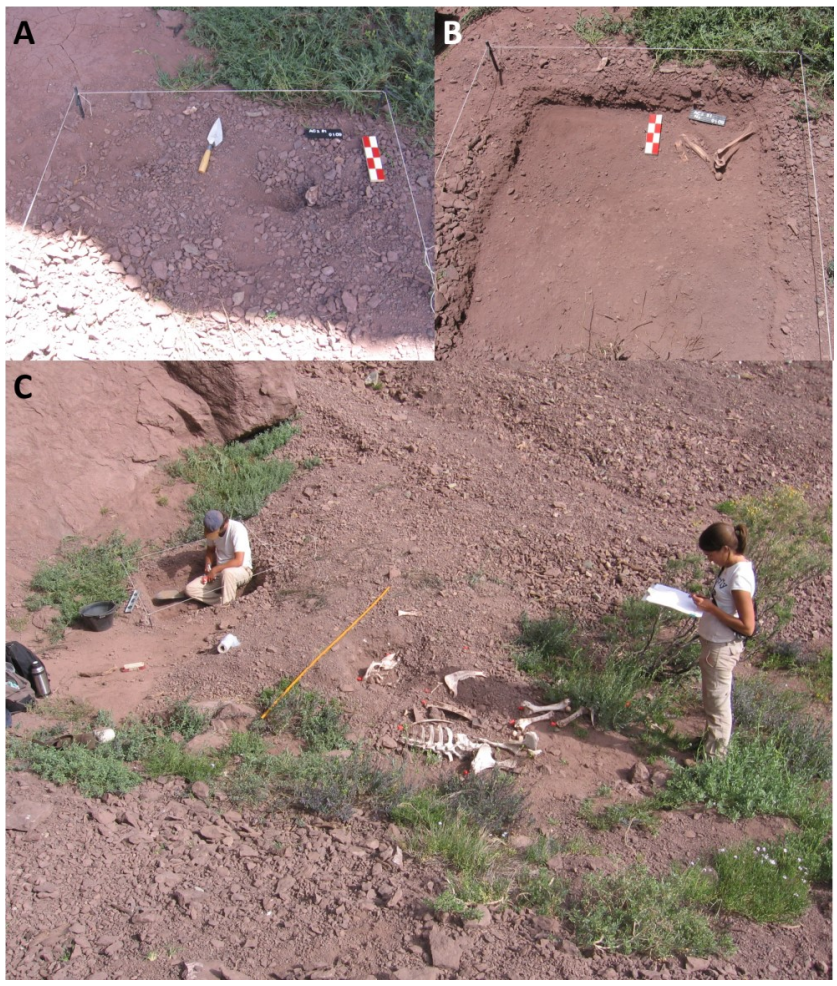

Figure 7 Test pit near Carcass 1. The Bones observed in $\mathbf{A}$ and $\mathbf{B}$ are part of Carcass 1 seen in $\mathbf{C}$. low in three of the four carcasses with none in Carcass 2. Weathering was a main variable affecting bone preservation. As shown in Figure 4, all carcasses have bones that reached stage 3 and Carcasses 1 and 3 have a few bones that reached stage 4 in the final observation.

From the information recovered in this study, it is possible to observe which processes predominate in each depositional context and make some comparisons with similar records in other parts of the world. Rock shelters are places where animals die because they offer shelter, and this was observed in our study and in other areas of Argentina (Cajal and Ojeda 1994; Cruz 1999; Rindel and Belardi 2006). The hearth detected in the rock shelter where Carcass 1 was deposited indicates that humans used this shelter as a refuge, and the presence of cattle bones suggests this place was probably used as shelter by animals too. In a taphonomic perspective, this implies a great potential for mixing of natural and cultural materials, and in this regard, it is necessary to consider the modifications a carcass suffers in a natural context like this. In our three-year study, we found little to no change in the number of bone specimens disarticulated from the carcass located in the rock shelter and no substantial weathering was observed. Horizontal dispersal was low in comparison with the carcasses located in the wet meadow and in the glacial moraine. Vertical migration was observed; a specific sequence of burial and re-exposure for some elements was recorded. The sediments surrounding the cranium of the carcass were partially removed by animals searching for nutrients within the carcass. Evidence for excavation by carnivores was observed in other actualistic studies carried out in this area (Otaola 2014). Excavation at this site allows us to infer a high rate of sediment deposition and also demonstrate that there are differences in bone burial in this small area. Over two years, some elements reached $38 \mathrm{~cm}$ in depth while others remained on the surface. This is different from 
what was observed in other actualistic studies of rock shelters, in which a thick layer of sheep dung prevented burial of bones (Rindel and Belardi 2006).

In archaeological sites located in lacustrine deposits or on river margins, one of the usual questions concerns the origin of the bone assemblage and the role of water in the formation of the deposit (Bonomo and Massigoge 2004; Gutiérrez and Kaufmann 2007; Kahlke and Gaudzinski 2005; Kaufmann and Gutiérrez 2004). Fluvial effects on faunal remains and the role of water in the formation of the faunal record have been closely studied (Behrensmeyer 1975; Fernandez Jalvo and Andrews 2003; Gutierrez and Kaufmann 2007; Nasti 2005; Trapani 1998; Voorhies 1969) and it has been demonstrated that bones have different displacement potential according to size, shape, and density, and that bones behave differently if they are dry or wet and articulated or disarticulated when they contact the water (Coard 1999). The carcass located in the wet meadow in our own study had articulated elements. In this case, the high energy of the wet meadow produced rapid bone burial. At the same time, fluvial processes and animal bioturbation produced significant horizontal displacement and vertical migration of elements. Therefore, in this context there was greater potential for mixing of archaeological and modern materials than at the other taphonomic sites of this study.

In the colluvial slope site, relatively rapid disarticulation and extensive horizontal dispersion of carcass portions took place. This landform also indicates a significant potential for horizontal mixing. Weathering was more rapid in this context than in other landforms such as the glacial moraine and rock shelter, probably due to higher exposure to weathering factors. As already mentioned, the rock shelter and moraine carcasses spend more time per year under snow and the wet meadow carcass suffered rapid burial since it is deposited in a waterlogged place and exposed to surface weathering for less time (Andrews and Whybrow 2005).

Finally, in moraine deposits the course of disarticulation was slow, and almost no burial was observed. Vertical mixing was less evident, but horizontal displacement was high. Scattering of bones could have been produced by carnivores. Weathering was light, but the slow burial rate decreases the potential for long-term preservation. The archaeological implications for similar landscape contexts, with sediments largely composed of coarse pebbles, indicate a high probability that zooarchaeological materials will be destroyed prior to burial, making preservation unlikely. As a result, we can expect only highly durable materials (e.g., lithic artifacts) to preserve well in such contexts.

\section{Conclusions}

The aim of this survey was to gain some understanding of the rates of weathering, dispersal, and burial of bones in a desert mountain environment. There have been few long-term studies of this nature in these kinds of environments, so even though this ongoing study is based on four skeletons in four different contexts, it offers some insight into taphonomic processes. From our observations, we infer that each context has its own taphonomic history, principally influenced by the geomorphic and ecologic processes that operate in different landforms (see summary in Lyman 1994, 2010). We summarize our key conclusions in three points:

1) Weathering, as was observed in other longitudinal studies (Andrews and Whybrow 2005), is difficult to generalize because it depends on the degree to which bones have been buried or exposed. Additional data on environmental variables are necessary for a better understanding of the effects of weathering in this area. The rainfall here averaged 200-600 $\mathrm{mm}$ per year and in some months snow covered the studied carcasses. In Carcasses 1 and 4, the snow covered them for longer periods than Carcasses 2 and 3, probably causing slower weathering. This hypothesis will be tested in future observations.

2) Dispersal of bones depends on the slope of the place where the carcass is located, geologic agents acting where the bones are deposited, and carnivore activity (Hill 1979).

3) Burial does not follow unidirectional processes. On the contrary, while some elements get buried very quickly, others could be buried and later resurfaced by carnivores or others agents as was noted in Carcass 1. The burial process depends on the sediments where the carcass was deposited and the geological agents acting in the geomorphology of the landforms.

The study of the nature of contemporary bone accumulations in natural contexts will help to understand the interactions of several agents of past environments. The data generated from these 
assemblages may be used for constructing hypotheses concerning the processes that affect animals between death and fossilization (Hill 1979). The conjunction of this kind of research with experimental actualistic studies where all the variables are controlled is necessary to construct unambiguous models of formation processes of the archaeological record in this area. Such studies began a few years ago (Corbat 2015; Corbat and Giardina 2014; Otaola 2013) and we will continue developing this actualistic line of research.

\section{Acknowledgements}

We thank the Corales family for their hospitality during our fieldwork, and Ramiro Barberena, Salvador Paulides, Adolfo Gil, and Gustavo Neme for helping during fieldwork. We also thank Steve Wolverton and Jonathan Dombrosky who helped with the English writing and for their valuable comments on the content of this paper. The review of three anonymous reviewers are appreciated and helped to improve the manuscript.

\section{Declarations}

Permissions: All permissions for fieldwork were provided by the Dirección de Patrimonio Cultural y Museos de la Provincia de Mendoza.

Sources of Funding: This work was possible thanks to financial support from the Consejo Nacional de Investigaciones Científicas y Técnicas (CONICET) and Agencia Nacional de Promoción Científica y Tecnológica (ANPCy'T).

Conflicts of Interest: None declared.

\section{References Cited}

Abraham, M., and F. Rodríguez Martínez, eds. 2000.

Recursos y Problemas Ambientales de Zona Árida. Primera Parte: Provincias de Mendoza, San Juan y La Rioja. Caracterización Ambiental. IADIZA, Mendoza, Argentina.

Andrews, P., and J. Cook. 1985. Natural Modifications to Bones in a Temperate Setting. Man 20:675691. DOI:10.2307/2802756.

Andrews, P., and P. Whybrow. 2005. Taphonomic Observations on a Camel Skeleton in a Desert Environment in Abu Dhabi. Palaeontlogia Electrónica 8. Available at: http://palaeoelectronica.org/2005_1/andrews23/andrews23.pdf. Accessed on January 28, 2016.
Behrensmeyer, A. K. 1975. The Taphonomy and Paleoecology of Plio-Pleistocene Vertebrate Assemblages East of Lake Rudolf, Kenya. Bulletin of the Museum of Comparative Zoology 146:473-578.

Behrensmeyer, A. K. 1978. Taphonomic and Ecologic Information from Bone Weathering. Paleobiology 4:150-162.

Behrensmeyer, A. K. 1991. Terrestrial Vertebrate Accumulations. In Taphonomy: Releasing the Data Locked in the Fossil Record, Vol. 9, Topics of Geobiology, edited by P. A. Allison and D. E. G. Briggs, pp. 291 -335. Plenum Press, New York, NY.

Behrensmeyer, A. K. 2007. Changes Through Time in Carcass Survival in the Amboseli Ecosystem, Southern Kenya. In Breathing Life into Fossils: Taphonomic Studies in Honour of C.K. (Bob) Brain, edited by T. Pickering, K. Shick, and N. Toth, pp. 137160. Stone Age Institute Press, Bloomington, IN.

Behrensmeyer, A. K., and S. M. Kidwell 1985. Taphonomy's Contribution to Paleobiology. Paleobiology 11:105-119.

Bernáldez Sanchez, E., E. García Viñas, A. Ocaña García de Veas, F. J. Vázquez Gil, M. Gamero Esteban, and A. V. Grimaldi. 2008. La Ecología de la Muerte: Bioestratinomía en la Sierra Norte de Sevilla. In Investigación Científica y Conservación en el Parque Natural Sierra Norte de Sevilla. Junta de Andalucia Consejería de Medio Ambiente, pp.184-209. Junta de Andalucía, Sevilla, Spain.

Blumenschine, R. J. 1989. A Landscape Taphonomic Model of the Scale of Prehistoric Scavenging Opportunities. Journal of Human Evolution 18:345371. DOI:10.1016/0047-2484(89)90036-5.

Borella, F., and L. A. Borrero 2010. Observaciones Tafonómicas Acerca de la Desarticulación de Carcasas de Pinnípedos en Ambientes Litorales, el Caso de Islote Lobos (Golfo San Matías, Río Negro). In Zooarqueología a principios del siglo XXI. Aportes teóricos, Metodológicos y Casos de Estudio, edited by M. Gutiérrez, M. De Nigris, P. Fernández, M. Giardina, A. Gil, A. Izeta, G. Neme, and H. Yacobaccio, pp. 371-380. Ediciones del Espinillo, Buenos Aires, Argentina.

Borrero, L. A. 2007. Longitudinal Taphonomic Studies in Tierra del Fuego, Argentina. In Taphonomy and Zooarchaeology in Argentina, edited by M. A. Gutierrez, L. Miotti, G. Barrientos, G. Mengoni 
Goñalons, and M. Salemme, pp. 219-233. BAR International Series 1601, Archaeopress, Oxford.

Borrero, L. A., N. V. Franco, J. L. Lanata, and J. B. Belardi. 1993. Distribuciones Arqueológicas y Tafonómicas en la Margen Norte del Lago Argentino (Santa Cruz, Argentina). Actas del XII Congreso Nacional de Arqueología Chilena 1:23-31.

Borrero, L. A., F. M. Martin, and J. Vargas. 2005. Tafonomía de la Interacción Entre Pumas y Guanacos en el Parque Nacional Torres del Paine, Chile. Magallania 33:95-114. DOI:10.4067/S071822442005000100007.

Bonomo, M., and A. Massigoge. 2004. Análisis Tafonómico del Conjunto Faunístico del Sitio Arqueológico Nutria Mansa 1 (Partido de General Alvarado). In Aproximaciones Contemporáneas a la Arqueología Pampeana: Perspectivas Teóricas, Metodológicas, Analiticas y Casos de Studio, edited by G. Martínez, M. A. Gutiérrez, R. Curtoni, M. Berón, and P. Madrid, pp. 93-111. Facultad de Ciencias Sociales (UNCPBA), Olavarría, Buenos Aries, Argentina.

Brain, C. K. 1967. Bone Weathering and the Problem of Bone Pseudo-tools. South African Journal of Science 63:97-99.

Brain, C. K. 1981. The Hunters or the Hunted? An Introduction to African Cave Taphonomy. The University of Chicago Press, Chicago, IL.

Cabrera, A. L. 1971. Regiones Fitogeográficas de Argentina, Enciclopedia Argentina de Agricultura y Jardinería, Tomo II, Fascículo I. Editorial ACME, Buenos Aires, Argentina.

Cajal, J. L., and R. A. Ojeda. 1994. Camélidos Silvestres y Mortalidad por Tormentas de Nieve en la Cordillera Frontal de la Provincia de San Juan, Argentina. Mastozoología Neotropical 1:81-88.

Capitanelli, R. 2005. Climatología de Mendoza. Editorial UNCUYO, Edición Facsimilar, Mendoza, Argentina.

Corbat, M. 2015. Variabilidad Ambiental y Sociocultural en la Explotación de Peces en el Centrooccidente Argentino: Una Evaluación Xooarqueológica. Unpublished Doctoral Dissertation, Facultad de Filosofía y Letras, Universidad de Buenos Aires, Buenos Aires, Argentina.

Corbat, M., and M. Giardina. 2014. Experimental Approach and Shape Influence on Hydraulic
Transport of Fish Bones. Paper presented at the 12th International Conference of Archaeozoology. San Rafael, Argentina.

Coard, R. 1999. One Bone, Two Bones, Wet Bones, Dry Bones: Transport Potentials under Experimental Conditions. Journal of Archaeological Science 26:1369-1375. DOI:10.1006/jasc.1999.0438.

Cruz, I. 1999. Estepa y Bosque: Paisajes Actuales y Tafonomía en el Noroeste de Santa Cruz: La Utilización de Lagos y Lagunas en la Región de Lago Argentino (Provincia de Santa Cruz). In Soplando en el Viento: Actas de las III Jornadas de Arqueología de la Patagonia, pp. 303-314. Universidad Nacional del Comahue e Instituto Nacional de Antropología y Pensamiento Latinoamericano, Neuquén, Buenos Aires, Argentina.

Cruz, I. 2007. Avian Taphonomy: Observations at Two Magellanic Penguin (Spheniscus magellanicus) Breeding Colonies and Their Implications for the Fossil Record. Journal of Archaeological Science 34:1252 -1261. DOI:10.1016/j.jas.2006.10.016.

Cruz, I., and S. Muñoz. 2010. Tafonomía Comparativa: Seguimiento de Carcasas de Mamíferos de Punta Entrada (Santa Cruz, Argentina). In Zooarqueología a Principios del Siglo XXI: Aportes Teóricos, Metodológicos y Casos de Estudio, edited by M. Gutiérrez, M. De Nigris, P. Fernández, M. Giardina, A. Gil, A. Izeta, G. Neme and H. Yacobaccio, pp. 387-396. Ediciones del Espinillo, Buenos Aires, Argentina.

Efremov, I. A. 1940. Taphonomy: A New Branch of Paleontology. Pan American Geologist 74:81-93.

Fernandez-Jalvo, Y., and P. Andrews. 2003. Experimental Effects of Water Abrasion on Bone Fragments. Journal of Taphonomy 1:147-163.

Gutiérrez, M. A, and C. Kufmann 2007. Criteria for the Identification of Formation Processes in Guanaco (Lama guanicoe) Bone Assemblages in Fluvial-Lacustrine Environments. Journal of Taphonomy 5:151-176.

Haynes, G. 1982. Utilization and Skeletal Disturbance of North American Prey Carcasses. Arctic 35:266281.

Hayned, G. 1988. Longitudinal Studies of African Elephant Death and Bone Deposits. Journal of Archaeological Science 15:131-157. DOI:10.1016/03054403(88)90003-9. 
Hill, A. 1979. Disarticulation and Scattering of Mammal Skeleton. Paleobiology 5:261-274.

Kahlke, R. D., and S. Gaudzinski. 2005. The Blessing of a Great Flood: Differentiation of Mortality Patterns in the Large Mammal Record of the Lower Pleistocene Fluvial Site of Untermassfeld

(Germany) and Its Relevance for the Interpretation of Faunal Assemblages from Archaeological Sites. Journal of Archaeological Science 32:1202-1222. DOI:10.1016/j.jas.2005.03.004.

Kaufmann, C. A., and M. A. Gutierrez. 2004. Dispersión Potencial de Huesos de Guanaco en Medios Fluviales y Lacustres. In Aproximaciones Contemporáneas a la Arqueología Pampeana: Perspectivas Teóricas, Metodológicas, Analiticas y Casos de Studio, edited by G. Martínez, M. A. Gutiérrez, R. Curtoni, M. Berón, and P. Madrid, pp. 129-146. Facultad de Ciencias Sociales (UNCPBA), Olavarría, Buenos Aries, Argentina.

Lagiglia, H. A, G. Neme, and A. Gil. 1994. Investigaciones Arqueológicas en la Cueva Arroyo Colorado (Malargüe- Mendoza). In Actas y Memorias del XI Congreso Nacional de Arqueología Argentina, edited by H. A. Lagiglia, pp. 119-120. San Rafael, Mendoza, Argentina.

Lyman, R. L. 1994. Vertebrate Taphonomy. Cambridge University Press, New York, NY.

Lyman, R. L. 2010. What Taphonomy Is, What It Isn't, and Why Taphonomists Should Care about the Difference. Journal of Taphonomy 8:1-16.

Marean, C. 1995. Of Taphonomy and Zooarchaeology. Evolutionary Anthropology 4:64-72. DOI:10.1002/ evan.1360040209.

Nasti, A. 2000. Modification of Vicuña Carcasses in High-Altitude Deserts. Current Anthropology 41:279_ 283. DOI:10.1086/300133.

Nasti, A. 2005. Dragging and Scattering of Camelid Bones by Fluvial Action in the Real Grande Gorge, Province of Catamarca, Southern Argentinean Puna. Journal of Taphonomy 3:173-183.

Neme, G. 2007. Caradores-Recolectores de Altura en los Andes Meridionales: el Alto Valle del Rio Atuel. BAR International Series 159, Archaeopress, Oxford.

Otaola, C. 2013. Zooarqueologia en la Cordillera del Sur de Mendoza: Un Enfoque Tafonómico.
Unpublished Doctoral Dissertation. Facultad de Filosofía y Letras, Universidad de Buenos Aires, Buenos Aires, Argentina.

Otaola, C. 2014. Actualistic Zooarchaeology in Central Western Argentina in Cave and Open Air Contexts. Ethnobiology Letters 5:95-103.

DOI:10.14237/ebl.5.2014.227.

Otaola, C., M. Giardina, M. Fry, G. Neme, and S. Wolverton. 2015. Zooarqueologia y Tafonomia en Pastores actuales del Sur de Mendoza. Manuscript submitted to Intersecciones en Antropología. Available from claraotaola@conicet.gov.ar.

Paruelo, J. M., A. Beltran, O. Sala, E. Jobbagy, and R. A. Golluscio. 1998. The Climate of Patagonia: General Patterns and Controls on Biotic Processes. Austral Ecology 8:85-104.

Rindel, D., and J. B. Belardi. 2006. Mortandad Catastrófica de Guanacos por Estrés Invernal y Sus Impplicaciones Arqueológicas: El Sitio Alero Los Guanacos 1. Magallania 34:139-155. DOI:10.4067/ S0718-22442006000100009

Roig, F. A., M. Carretero, and E. Méndez. 2000. Vegetación de la Provincia de Mendoza. In Recursos y Problemas Ambientales de la Zona Árida: Provincias de Mendoza, San Juan y La Rioja. Caracterización Ambiental, edited by E. M. Abraham and F. R. Martinez, pp. 63-70. IADIZA, Mendoza, Argentina.

Trapani, J. 1998. Hydrodynamic Sorting of Avian Skeletal Remains. Journal of Archaeological Science 25:477-487. DOI:10.1006/jasc.1997.0257.

Voorhies, M. 1969. Taphonomy and Population Dynamics of an Early Pliocene Vertebrate Fauna, Knox County, Nebraska. Contributions to Geology Special Paper 1. University of Wyoming, Laramie, WY.

Weigelt, J. 1989. Recent Vertebrate Carcasses and their Paleobiological Implications. The University of Chicago Press, Chicago, IL.

Wolverton, S., J. Dombrosky, and R. L. Lyman. 2014. Practical Significance: Ordinal Scale Data and Effect Size in Zooarchaeology. International Journal of Osteoarchaeology. DOI:10.1002/oa.2416. 